\title{
Fragmenta Manuscriptorum Musicalium Hungariae Mediaevalis: From Traditional Methodologies Towards a Digital Corpus
}

\begin{abstract}
The paper focuses on the latest results and achievements of the research group Digital Musical Fragmentology established at the Department of Early Music History of the Institute for Musicology in Budapest. The research is closely related to the decades-long musical, liturgical and palaeographical examination of sources, repertories, melodic and notation systems of the cantus planus in Hungary and Central Europe. After discussing the main principles of describing, systemising and analysing notated manuscript fragments on the website Fragmenta Manuscriptorum Musicalium Hungariae Mediaevalis two casestudies are presented in detail: fragments of a fifteenth-century Graduale Strigoniense and those of the Sequentionale Waradiense. Both are contributing to a virtual reunification of disseminated groups of fragments, dispersed in different libraries, towns, countries.
\end{abstract}

The study of manuscript fragments is an especially vital task in a country that has lost the vast majority of its medieval manuscripts. On the basis of extant descriptions, inventories and catalogues, it was estimated that roughly 50,000 manuscripts could have existed in medieval Hungary, while only 1,500 of these survive. ${ }^{1}$ The causes of this considerable loss in Hungary are twofold or, rather, they can be related to two phenomena. The first, expectedly, is rooted in the general vicissitudes of history, the second is a result of the unique historical, political, and cultural context of Hungary, particularly the great difference between the current and the medieval borders of the country. Parallel to other similar trends around Europe, it was in sixteenth- and seventeenth-century Hungary that

1 See the rough estimate made by László Mezey in the late 1970s: Mezey 1978.

Note: The research is funded by the Hungarian National Research, Development and Innovation Office, Project Number 120643.

Ә Open Access. () 2020 Zsuzsa Czagány, published by De Gruyter. (cc) BY-NC-ND This work is licensed under the Creative Commons Attribution-NonCommercial-NoDerivatives 4.0 International License.

https://doi.org/10.1515/9783110717884-012 
old parchment codices were broken up and used as wrappers or to strengthen the bindings of paper books. Several sources indicate that bookbinders bought highquality parchment by the sheet to bind newly printed pages or stacks of documents. ${ }^{2}$ Hungarian scholarly literature often quotes the will of István Báthory, judge royal (comes curialis) of the Kingdom of Hungary, ${ }^{3}$ written in 1603 to indicate a shift in the perception of old liturgical manuscripts in the early Modern Era: 'The old books should be cut up and given to schoolchildren and be used to bind books'. ${ }^{4}$

However, the drastic loss of codices, and the lack of information about them is not only the result of these processes. The fact that the territory of the medieval Kingdom of Hungary was almost three times that of the modern country is also a contributing factor. Once the northern, southern and eastern regions of the medieval kingdom became sovereign states, the manuscripts extant in their territories became, for many years, inaccessible to Hungarian scholars. Twentieth-century Hungarian scholars could only rely on old descriptions and literary references - often predating scientific methodologies - for reconstructing the typology and use of historical documents in these areas. Moreover, scholars had no information about the extent of surviving manuscripts and records in the archives of the old religious centres of Hungary, such as the Pozsony (Bratislava), Szepes (Spiš) and Nagyszombat (Trnava) Chapters in modern day Slovakia, the Bishoprics of Kolozsvár (Cluj-Napoca) and Gyulafehérvár (Alba Iulia) in current Romania, and the Zagreb Cathedral in today's Croatia. Thankfully, in these cases the loss of information was only temporary. Political and cultural shifts that unfolded at the end of the twentieth and beginning of the twenty-first century - the opening up of archives, free movement of information and new forms of scientific and scholarly cooperation resulted in the rediscovery of many sources hitherto thought to be lost, not only in neighbouring countries, but also in regions far from medieval Hungary.

An example directly connected to the field of chant research can shed more light onto this process. In the 1990s, as strict limitations on travel were eased, a group of Hungarian chant scholars and restorers were allowed to visit the Imperial Treasury of the Topkapı Palace in Istanbul. The fact that the Imperial Treasury held artefacts of Hungarian origin among others medieval documents, taken

2 See Mezey in Mezey et al. 1983, 15.

3 István (Stephen) Báthory of Ecsed, judge royal (comes curialis / iudex curiae regiae) from 1585 to 1605 .

4 Parts of the testament were published by Komáromy 1890, 124-141. The full text is available in the edition by Vadász 2002, 36. 
as loot during the 150-year-long Ottoman occupation of Hungary, was well documented in scholarly literature. ${ }^{5}$ The German theologian, Adolf Deissmann published a catalogue in $1933,{ }^{6}$ which listed a medieval gradual, known as the 'Graduale Francisci de Futhak ${ }^{7}$. The fifteenth-century manuscript has been accessible on black and white microfilm since $1972 .{ }^{8}$ In 1989 the news of the discovery of an antiphoner were published along with a few sample images. ${ }^{9}$ The outcome of complex diplomatic negotiations, the 1997 visit was organised primarily to give Hungarian scholars ${ }^{10}$ a chance to examine these manuscripts in Istanbul. Once there, the research group discovered three other complete notated manuscripts beside the gradual and antiphoner. ${ }^{11}$ One of the five codices is the Antiphonale Strigoniense, the so-called 'Istanbul Antiphoner', which was completed around 1360 and was previously only known from some partial reproductions. Since 1999 a high-quality facsimile edition is also available. ${ }^{12}$ The manuscript is an important source for medieval Hungarian music, both for the palaeographical aspect and for its contents, representing the mature Esztergom liturgical and musical tradition.

Musical fragmentology in Hungary began in the 1970s, connected to the beginnings of the study of manuscript fragments as an independent discipline. In fact, it can be said that the first success of 'institutionalised' fragmentology in Hungary was locating and classifying medieval liturgical sources with musical notation. The theoretical father and first researcher in the study of manuscript fragments in Hungary was László Mezey. In 1972, Mezey created the Fragmenta Codicum study group of the Hungarian Academy of Sciences, the first project that began to describe and publish systematically medieval manuscript fragments from Hungary, in parallel with similar initiatives around Europe. Mezey was the

5 The Hungarian scholars Arnold Ipolyi, Imre Henszlmann and Ferenc Kubinyi visited the Topkap1 Palace in 1862. In 1889 the second delegation from the Hungarian Academy of Sciences discovered in the Treasury four liturgical manuscripts of Hungarian origin. See Ungarische Revue, 9/6 (1889), 733.

6 Deissmann 1933.

7 Deissmann 1933, n. 68, olim 2429.

8 Microfilm Archives of the Department of Early Music at the Institute for Musicology of the Hungarian Academy of Sciences.

9 Vízkelety 1989, 99-101.

10 László Dobszay and Janka Szendrei from the Institute for Musicology of the Hungarian Academy of Sciences.

11 Deissmann no. 60: Missale notatum saec. 13; Deissmann no. 49: Missale notatum saec. 14; Deissmann no. 43: Antiphonale OFM pars hiemalis saec. 14/2. For a detailed description of the Istanbul manuscripts see Szendrei 2001.

12 Szendrei et al. 1999. 
first scholar to formulate the thesis that the value of fragments as historical sources goes beyond their incomplete, fragmentary nature, providing researchers with an insight into the original manuscript source. ${ }^{13}$ The Fragmenta Codicum workshop - since 1998 called Res Libraria Hungariae 'Fragmenta Codicum' - published the catalogues of manuscripts and fragments of six Hungarian collections between 1983 and 2007, and it is still active to the present day. ${ }^{14}$

The one and, so far, only catalogue of medieval music manuscript fragments published in Hungary, Notated sources of the Hungarian Middle Ages [A magyar középkor hangjegyes forrásai] by Janka Szendrei, was published in 1981, preceding the first Fragmenta Codicum volume by two years. ${ }^{15}$ The catalogue described 131 complete notated liturgical manuscripts, 68 missals with sporadic musical notation, and 655 fragments. It provided the first overview of notated fragments, defining their liturgical contents, melodic variants of chants, and the type of musical notation. Szendrei's catalogue was the first work to illustrate the importance of an analysis of the musical content in the study of medieval manuscript fragments, emphasising how sometimes the type of musical notation, or a particular melodic variant may be the only information that can be used to infer the origin of a fragment, when other methodologies, like traditional codicological or palaeographical analyses, fail. In the thirty-five years since the publication of the Szendrei catalogue, the number of known notated manuscript fragments in Hungary has increased considerably. A small number of these newly-discovered fragments were included in the Fragmenta Codicum series; those containing musical notation were described in a separate section (Liturgica cum cantu). Alongside codicological descriptions, the particular type of musical notation is also identified, and the results of the musical and liturgical analyses summarised. So far, a total of 342 fragments have been described.

Neither the number of fragments published, nor their short descriptions comply with the professional expectations of music fragment databases in the present day, and the recent trends in research. In comparison to other Central European initiatives (Slovak, Czech or Austrian), Hungary has fallen behind in the publication of fragment catalogues both printed, as well as online. In 2016, the research team at the Department of Early Music of the Institute for Musicology at the Hungarian Academy of Sciences successfully applied for a grant with the

13 Mezey 1973, 211-213. For a summary of the first results see Mezey 1978.

14 Mezey et al. 1983; Mezey et al. 1988; Vizkelety et al. 1993; Vizkelety et al. 1998; Madas et al. 2006; Vizkelety 2007.

15 Szendrei 1981. 
title Codices and Fragments from Late Medieval Hungary. Examining, Reexamining and Online Publishing of Notated Manuscripts and Chant Repertories. ${ }^{16}$ The aim of the project is to discover, classify and describe notated medieval manuscript fragments from Hungary. One of the outcomes of the four-year project is the creation of the Fragmenta Manuscriptorum Musicalium Hungariae Mediaevalis website, which will collect the fragments into a database, make them freely accessible online. ${ }^{17}$

\section{The Database}

The database provides three levels of information: basic data, content, and analytical description.

\subsection{Basic data}

Bibliographical data, genre and date are summarised on the first level of description, alongside information on the extent and physical state of the source(s) (see Table 1). Basic codicological parameters, like page size, dimensions of the writing block, column size, number of lines and columns, and stave height are also listed here. These are complemented by information on the type of text script and musical notation used. As the vast majority of the sources described are of Central European origin, special attention is given to examining the medieval gothic types of musical notation, characteristic of a particular region, on a level that improves the traditional approaches of musical palaeography. Further to the description of the notation, other features of the notational system are also included, such as the colours of the staves, the unique shape of the custos or its absence, and special neume-forms. The first level of description is completed with information on the carrier (liber tradens) and the possessors, as well as relevant bibliographical references, like earlier catalogues. This level does not include information on the contents of the fragment, but only a short indication of the liturgical feast.

16 Grant no. 120643 of the National Research, Development and Innovation Office in Hungary. Project duration: 2016-2020, Principal Investigator: Zsuzsa Czagány.

$17<$ http://fragmenta.zti.hu $>$ (accessed 15 Sept. 2020). 
Table 1: The basic level of fragment description.

\begin{tabular}{ll}
\hline Date & Stave height \\
Archive & Script \\
Shelf-mark & Notation \\
Material & Notation/remarks \\
Extent & Carrier $1 . / 2 . / \ldots$ \\
Page height / width & Possessor \\
Writing block height / width & Content \\
Number of columns / lines & Origin \\
Number of lines & Bibliography / References \\
Width of columns & \\
\hline
\end{tabular}

\subsection{Content}

The in-depth analysis of liturgical contents pertains to the second level of description (see Table 2). All chants in the fragment are identified, and the liturgical use of the original manuscript is also determined on the basis on three, or four parameters: the time of the liturgical year (Tempus), the feast (Dies), the hour (Hora), and the genre, depending on whether the fragment came from a book for the Mass or for the Office, or from the temporale or sanctorale. Musical identification is made possible through the incipit, the mode, and the cantus identification number, which will be connected to the cantus database.

Table 2: Description of the liturgical content of the fragment.

\begin{tabular}{ll}
\hline NUMERUS & HORA \\
RISM & GENRE \\
FOLIO & INCIPIT \\
TEMPUS & MODE \\
DIES & CANTUS ID \\
\hline
\end{tabular}




\subsection{Analytical description}

The third level contains a deeper analysis of unique contents, and draws together the results of the liturgical, musical, and palaeographical observations, in order to propose new pathways for further research on the material (see Table 3).

Even though the work is still in its early stages, and the system of data entry might undergo some modifications during the course of the project, research has already yielded significant results. A number of new fragments have been discovered that not only increase the quantity of sources from Hungary, but shed light also on strong relations within groups of sources, thus revealing the existence of previously unknown scriptoria. In most cases, each fragment is representative of a single, lost original manuscript. However, in some cases, the collected data show connections between fragments that would otherwise be considered unrelated: such correspondences might consist in a complete match, revealing the common provenance of two or more fragments from the same original manuscript; or they might point to a different correlation, through which useful information about medieval book culture, manuscript production, and distribution can be equally gained.

\section{Two case-studies}

The last part of this paper will present two cases for which the detailed examination of both the material form and the content of fragments allowed a more precise reconstruction of the historical document.

\subsection{Fragments of a fifteenth-century Graduale Strigoniense}

One of the first institutions where medieval fragments with musical notations were described was the Collection of Manuscripts and Rarities of the University Library in Budapest. ${ }^{18}$ Among the sixty fragments used as covers of sixteenth- and seventeenth-century books and documents, later detached during restoration and stored in boxes without catalogue numbers, a single folio of a fifteenthcentury gradual was found, removed from the binding of the incunable Inc. 260

18 Special thanks should be given to György Cséka and Zsuzsanna Mód, the previous and current heads of the Collection of Manuscripts and Rarities for supporting our research. 
(see Figs 1a-b). ${ }^{19}$ Despite being torn around the edges and pierced at points, the parchment leaf is almost complete. The fragment contains seven lines of text with musical notation, and was probably part of the commune sanctorum section of a gradual; this is confirmed by the extant chants and their ordering. Table 3 shows the basic codicological and palaeographical data.

Table 3: Fragment Budapest, University Library Inc. 260, Basic Data.

\begin{tabular}{ll}
\hline Date & s. 15 \\
Archive & Budapest, University Library, Collections of Manuscripts and \\
& Rarities \\
Shelf-mark & Inc. 260 (carrier) \\
Material & Parchment \\
Extent & 1 single leaf, incomplete, removed \\
Page height / width & $362 \mathrm{~mm}$ (incomplete) / $235 \mathrm{~mm}$ (incomplete) \\
W. block height / width & $337 \mathrm{~mm}$ (incomplete) / $216 \mathrm{~mm}$ (incomplete) \\
Number of columns / lines & $1 / 7$ \\
Width of columns & - \\
Stave height & $30 \mathrm{~mm}$ \\
Script & gothica textualis \\
Notation & Messine gothic-Hungarian \\
Notation / remarks & 5 -line staves with lines traced in red, C-clef, F-clef, custos \\
Carrier 1. & $\mathrm{n} / \mathrm{a}$ \\
Carrier 2. & Inc. 260 \\
Possessor & $\mathrm{n} / \mathrm{a}$ \\
Content & Commune sanctorum / commune unius martyris pontificis \\
Origin & Hungary \\
Bibliogr./References & \\
\hline
\end{tabular}

19 Ninety-one fragments with musical notation kept in the University Library in Budapest were listed and described in Mezey et al. 1983. The sixty fragments mentioned here are stored separately and are not included in the catalogue. 


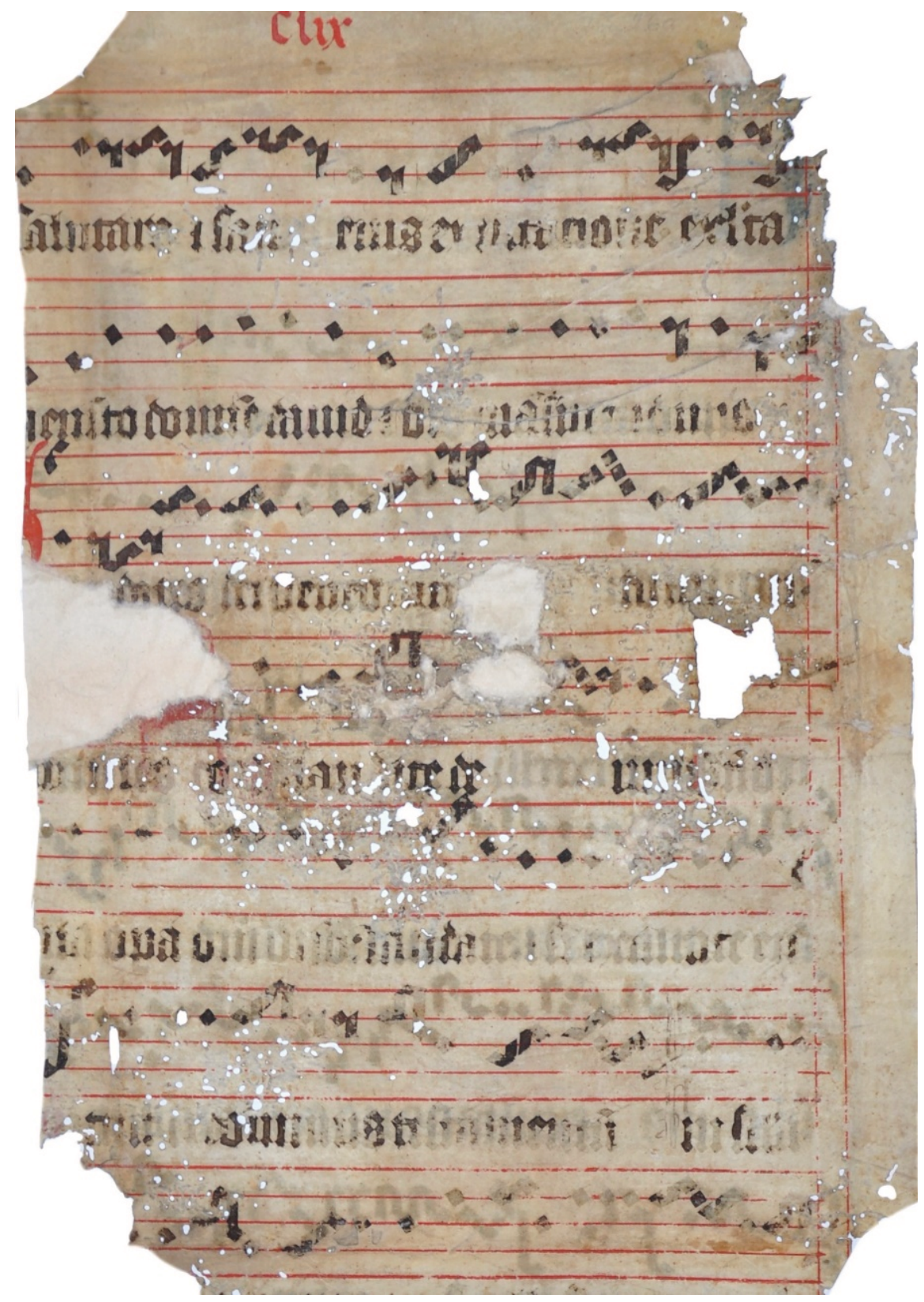

Fig. 1a: Budapest, University Library, fragment removed from Inc. 260, recto; @ Budapest, University Library. 


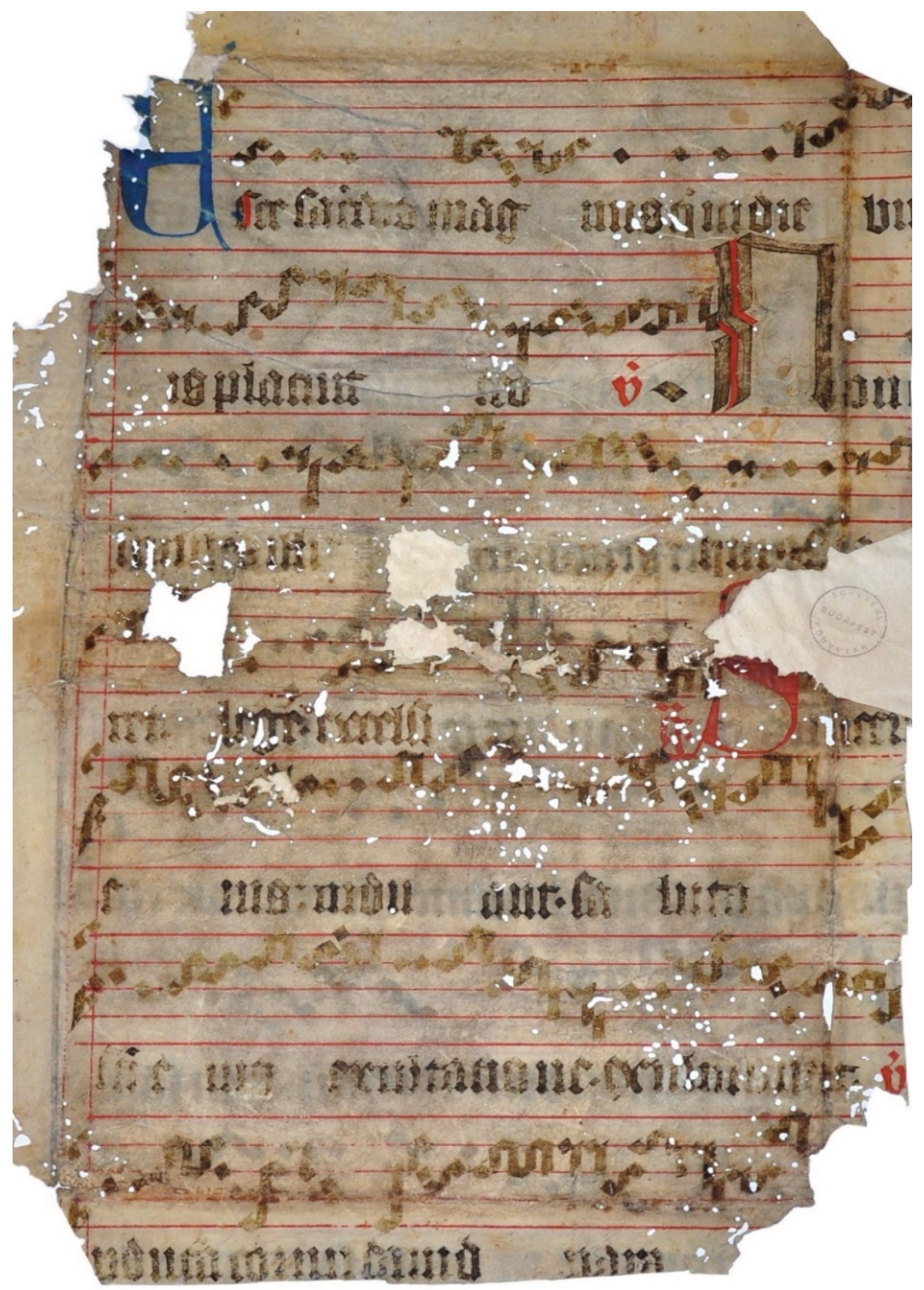

Fig. 1b: Budapest, University Library, fragment removed from Inc. 260, verso; @ Budapest, University Library. 
The recto transmits a series of five introits and their corresponding Psalm verses, while the verso contains four graduals and their verses (see Table 4). Instead of regular Mass-proper cycles following one another - as in the usual organisation of the proprium de tempore, or de sanctis - the fragment lists chants by genre, in a way that can be revealing of the category of saints in the commune sanctorum; in the case of this fragment this was probably the commune unius martyris pontificis.

Table 4: Fragment Budapest, University Library Inc. 260 (F 722), Contents.

\begin{tabular}{|c|c|c|c|c|c|c|c|}
\hline Folio & Tempus & Dies & Hora & Genre & Incipit & Mode & CANTUS ID \\
\hline \multirow[t]{5}{*}{ recto } & & $\begin{array}{l}\text { Commune un. } \\
\text { mart. pont. }\end{array}$ & & Intr & $\begin{array}{l}\text { Sacerdotes eius induant } \\
\quad \text { salutare }^{* 20}\end{array}$ & 2 & g02264 \\
\hline & & & & Intr-V & Memento Domine David & 2 & g02264a \\
\hline & & & & Intr & $\begin{array}{l}\text { Sacerdotes Dei } \\
\quad \text { benedicite Dominum* }\end{array}$ & 6 & g01280 \\
\hline & & & & Intr-V & $\begin{array}{l}\text { Benedicite omnia opera } \\
\text { Domini* }\end{array}$ & 6 & g01280a \\
\hline & & & & Intr & $\begin{array}{l}\text { Statuit ei Dominus } \\
\text { testamentum* }\end{array}$ & 1 & g01271 \\
\hline \multirow[t]{4}{*}{ verso } & & $\begin{array}{l}\text { Commune un. } \\
\text { mart. pont. }\end{array}$ & & Grad & Ecce sacerdos magnus* & 5 & g01332 \\
\hline & & & & Grad-V & Non est inventus* & 5 & g01332a \\
\hline & & & & Grad & $\begin{array}{l}\text { Sacerdotes eius induant } \\
\text { salutare }\end{array}$ & 1 & g01339 \\
\hline & & & & Grad-V & $\begin{array}{l}\text { Illuc producam cornu } \\
\text { David* }\end{array}$ & 1 & g01339a \\
\hline
\end{tabular}

The notation used in the fragment is a unique combination of Hungarian notation, so-called Strigonian notation, common in medieval Hungary between the twelfth and fourteenth centuries (and used even later in certain workshops), and the Messine-German-Gothic notation, which spread through the fourteenth century and became predominant in various local forms throughout Central-Europe. ${ }^{21}$ This

20 The asterisk indicates that the chant is incomplete.

21 For the description of the various notational types common in late medieval Central European liturgical manuscripts we chose to employ the terminology and typologies developed by 
mixed Messine-Gothic-Hungarian system of notation was used in the mid-fifteenthcentury scriptoria of Buda and Esztergom. Since this notation was particularly wellsuited for the compilation of large display manuscripts, the system was adapted into a monumental late-medieval ornamental writing style. Variants of this notation can be found in the high-grade manuscript production of fifteenth-century Hungary, such as the two-volume Esztergom Antiphoner, ${ }^{22}$ the already-mentioned Graduale Francisci de Futhak, ${ }^{23}$ the Buda Antiphoner ${ }^{24}$, and the Graduale Strigoniense of archbishop and cardinal Tamás Bakócz. ${ }^{25}$

The notational system of the fragment is comparable to that of the first volume of the Esztergom Antiphoner. ${ }^{26}$ Alongside similarities in the layout of the pages and the style of the staves (double lined red margins, five-line red staves, clefs and custodes) both contain neume groupings that can be put in relation to the set, sinuous style of the Strigonian notation. The round pes and the characteristic scandicus are also present, preserving the characteristics of the Esztergom system even in their modified forms. The similarities between the musical notation of the antiphoner and the fragment of the gradual are so great that it would be legitimate to infer that the two codices were written in the same scriptorium. The fragment can, thus, be considered to come from a 'sister' codex of the Esztergom Antiphoner, a hypothetical Graduale Strigoniense, copied in the middle of the fifteenth century. Previously only one folio was known from the gradual, but now, thanks to the new initiative we could discover more fragments from the same manuscript: one in the Diocesan Archives in Szombathely (Savaria), West-Hungary (Figs 2a-b), the second in the Diocesan Library of the same city (Figs 3a-b). ${ }^{27}$

Janka Szendrei, as the result of her fourty-year-long research in music palaeography and manuscript studies. See Szendrei 1986; Szendrei 1988a, 437-446; Szendrei 1988b, 5-234; Szendrei 1997, 257-274; Szendrei 1998, 267-282.

22 Antiphonale Strigoniense I-II: Esztergom, Cathedral Library, MS I. 3. c, I. 3. d; the description and the contents of both antiphoners are accessible on the website Hungarian Chant Database, $<$ hun-chant.eu> (accessed 15 Sept. 2020).

23 Istanbul, Topkapı Sarayı: Deissmann 1933, n. 68, olim 2429.

24 Antiphonale Budense: Štátny archív v Bratislave (Bratislava State Archives) EC Lad 6. Accessible online on the website <cantus.sk $>$.

25 Graduale Strigoniense Thomae card. Bakócz: Esztergom, Cathedral Library, MS I. $1 \mathrm{a}-\mathrm{b}$; the description and the contents are accessible on <hun-chant.eu>. Facsimile edition of the manuscript by Szendrei 1993.

26 Antiphonale Strigoniense II: Esztergom, Cathedral Library, MS I. 3. d.

27 First mentioned by Szigeti 1962, 64-73. 
The repertory of the Holy Week (Hebdomada Passionis) is quite uniform in Western plainchant manuscripts. Part of this uniform repertory is present in the gradual discussed here and illustrated in Table 5.

Table 5: Fragment Szombathely, Diocesan Archives, V. 48/E. fasc. (F901), Contents.

\begin{tabular}{|c|c|c|c|c|c|c|c|}
\hline Folio & Tempus & Dies & Hora & Genre & Incipit & Mode & CANTUS ID \\
\hline \multirow[t]{3}{*}{ recto } & Hebd. Passionis & Feria 5 & & Intr & $\begin{array}{l}\text { Omnia quae fecisti } \\
\text { nobis* }\end{array}$ & 2 & g01237 \\
\hline & & Feria 5 & & Grad & $\begin{array}{l}\text { Tollite hostias et in- } \\
\text { troite in atria* }\end{array}$ & 2 & g00822 \\
\hline & & Feria 5 & & Grad-V & Revelavit Dominus* & 6 & g00822a \\
\hline \multirow[t]{4}{*}{ verso } & Hebd. Passionis & Feria 5 & & Grad-V & $\begin{array}{l}\text { Revelavit Dominus* } \\
\quad \text { (cont.) }\end{array}$ & 6 & g00822a \\
\hline & & Feria 5 & & Off & $\begin{array}{l}\text { Super flumina Babilo- } \\
\text { nis* }\end{array}$ & 1 & g01239 \\
\hline & & Feria 5 & & Comm & $\begin{array}{l}\text { Memento verbi tui } \\
\text { servo tuo* }\end{array}$ & 5 & g01240 \\
\hline & & Feria 6 & & Intr & $\begin{array}{l}\text { Miserere mihi Domine } \\
\text { quoniam* }\end{array}$ & 5 & g00824 \\
\hline
\end{tabular}

The fragment from the Szombathely Diocesan Library (Figs 3a-b), on the other hand, contains the introits and graduals of the commune virginum ordered by genre, similarly to the above-mentioned fragment from the University Library in Budapest (see Table 6). 


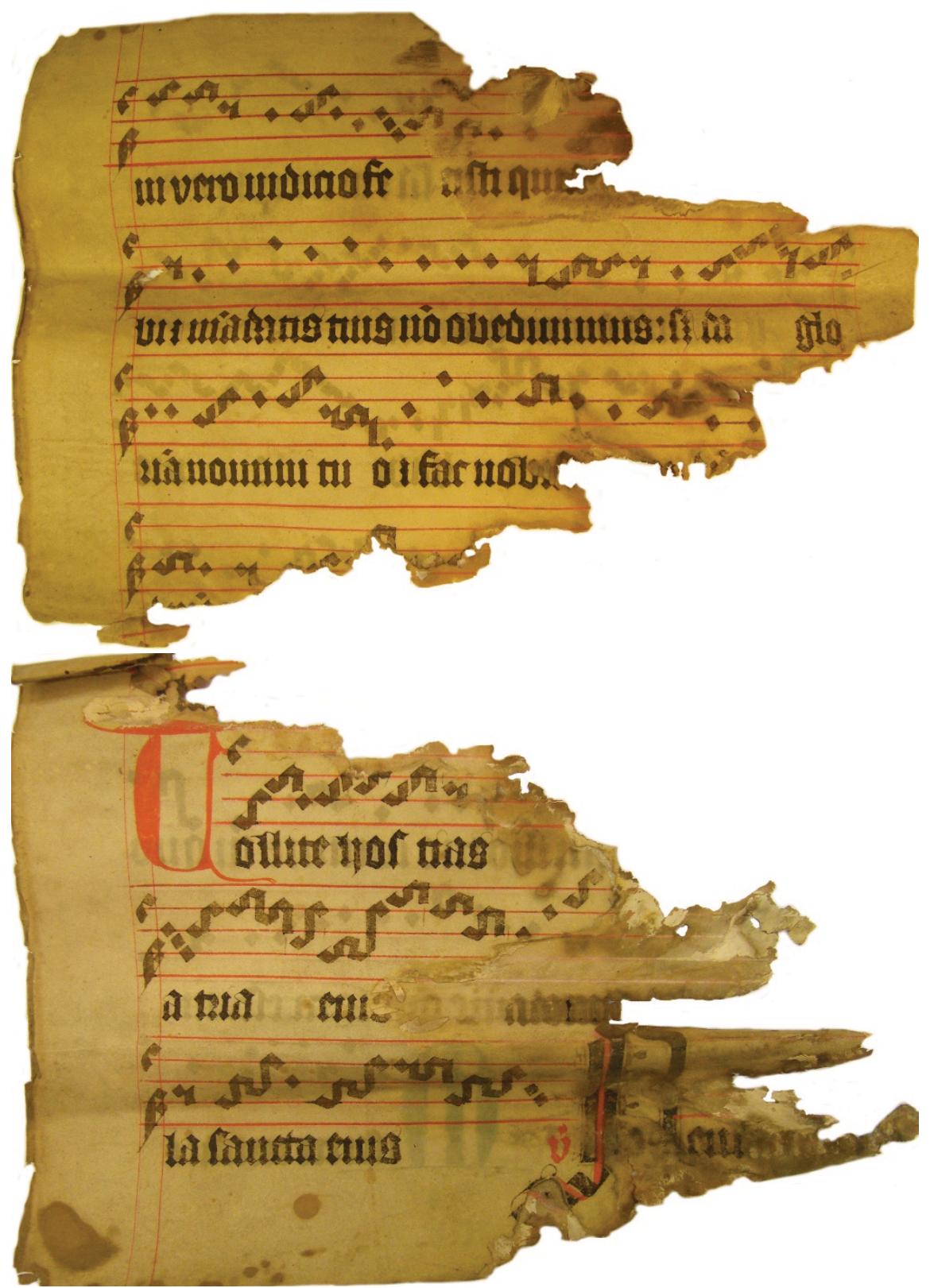

Fig. 2a: Szombathely, Diocesan Archives, fragment V. 48/E. fasc., recto; (c Szombathely, Diocesan Archives. 


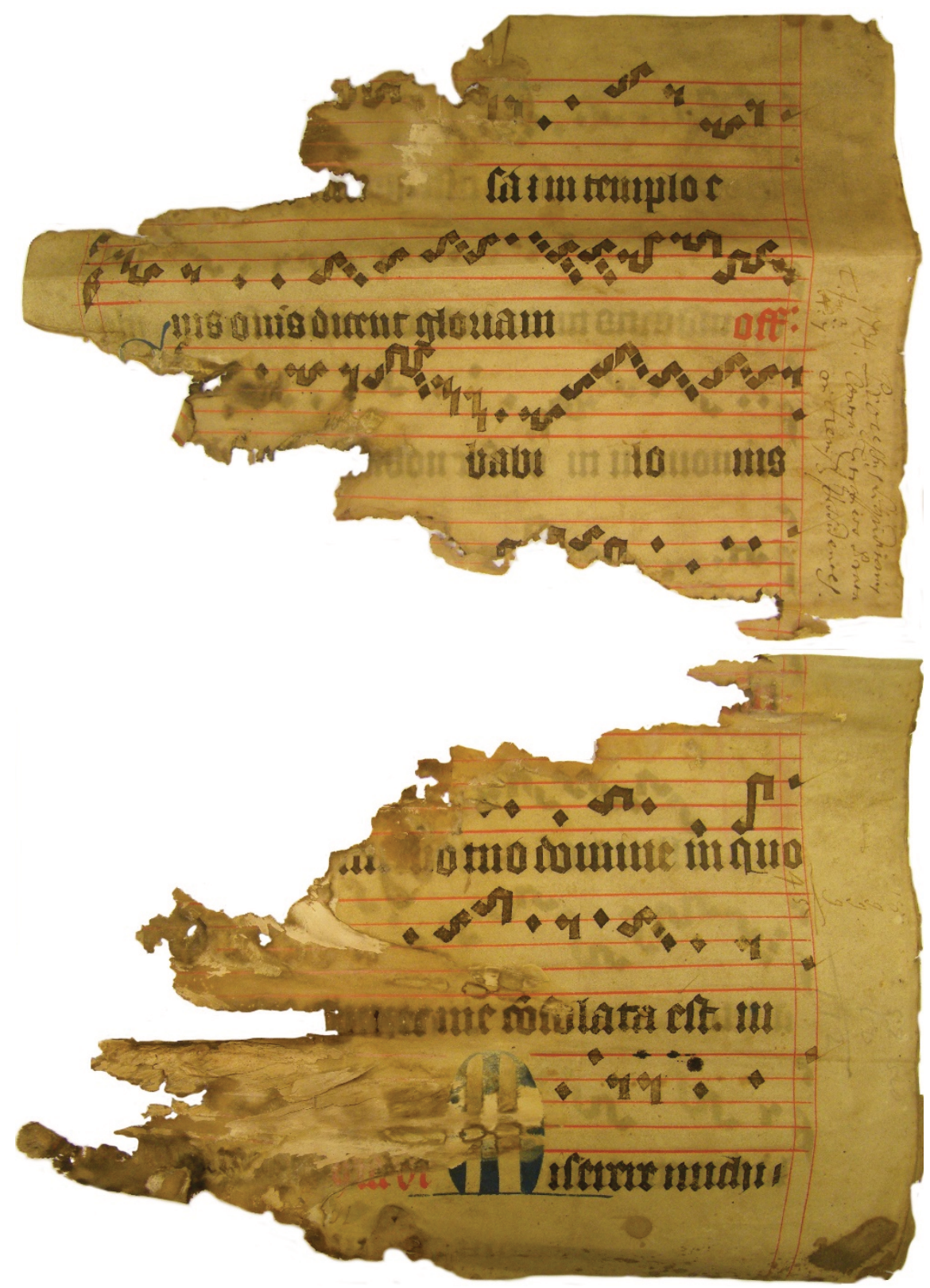

Fig. 2b: Szombathely, Diocesan Archives, fragment V. 48/E. fasc., verso; @ Szombathely, Diocesan Archives. 


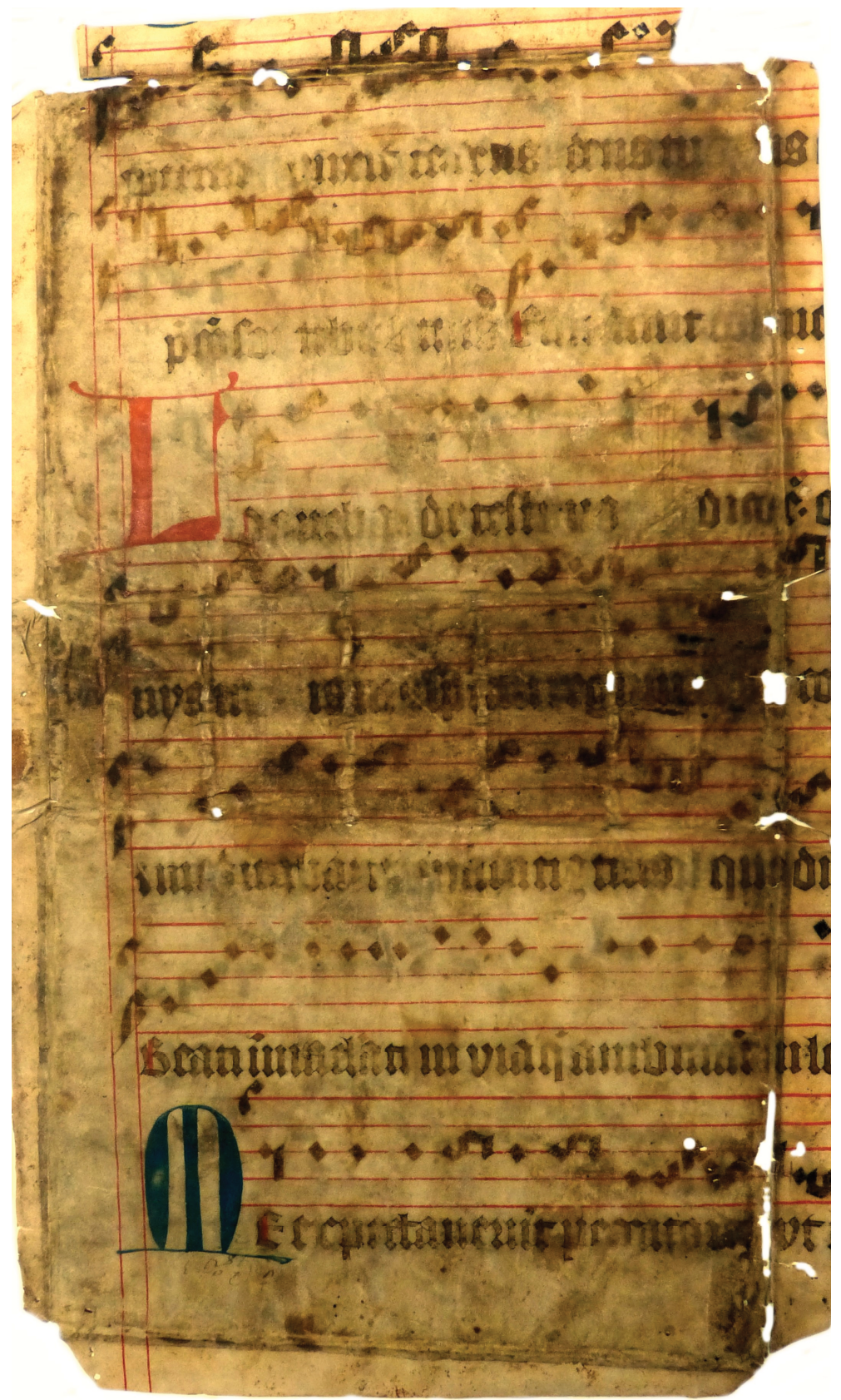

Fig. 3a: Szombathely, Diocesan Library, fragment sine sign., recto; @ Szombathely, Diocesan Library 


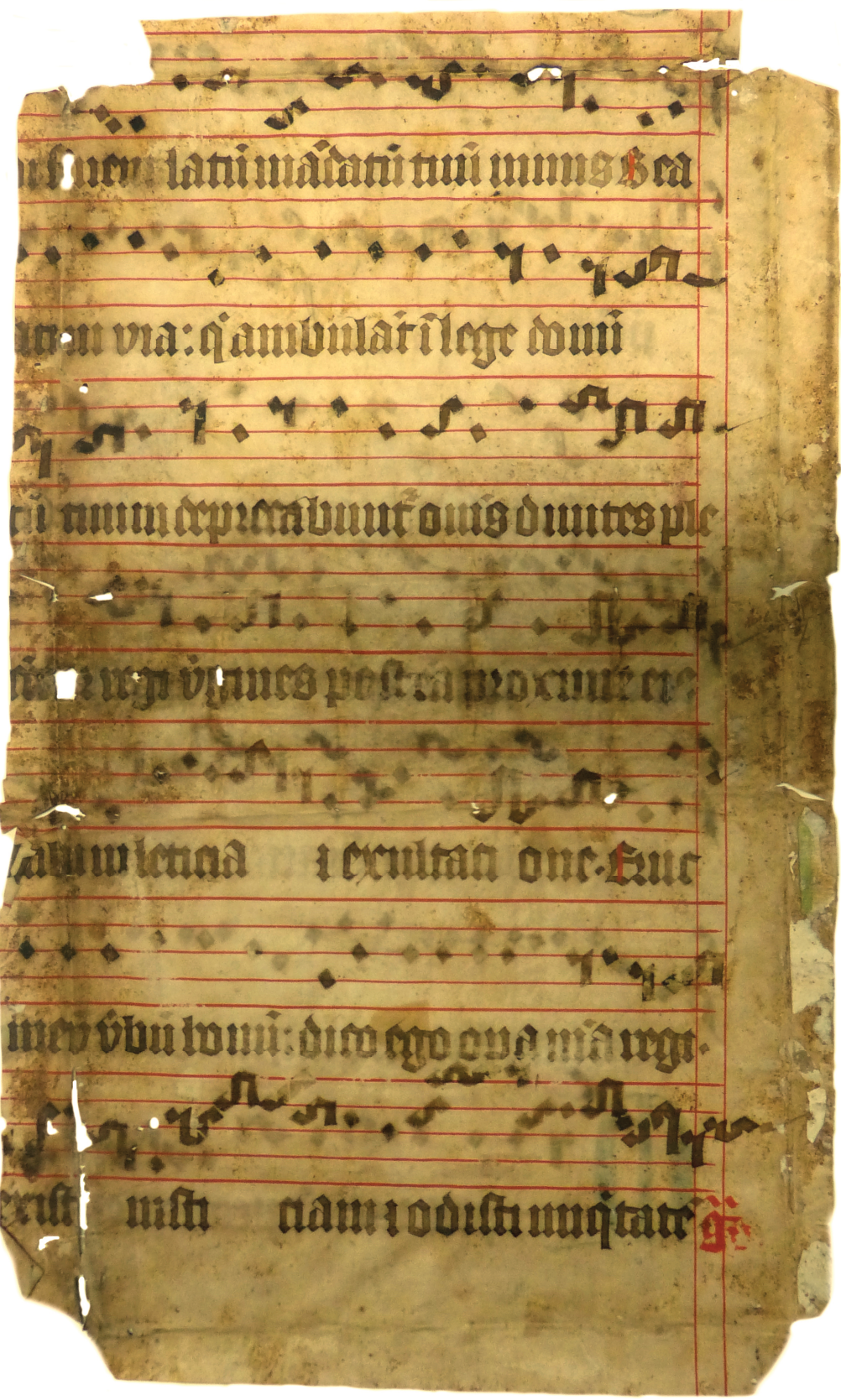

Fig. 3b: Szombathely, Diocesan Library, fragment sine sign., verso; @ Szombathely, Diocesan Library. 
Table 6: Fragment Szombathely, Diocesan Library, sine sign. (F900), Contents.

\begin{tabular}{|c|c|c|c|c|c|c|c|}
\hline Folio & Tempus & Dies & Hora & Genre & Incipit & Mode & CANTUS ID \\
\hline \multirow[t]{5}{*}{ recto } & & Commune vv. (?) & & Intr & $\begin{array}{l}\text { Dilexisti iustitiam et } \\
\text { odisti }\end{array}$ & 8 & g01380 \\
\hline & & & & Intr-V & Eructavit cor meum* & 8 & g01380a \\
\hline & & & & Intr & $\begin{array}{l}\text { Loquebar de testimoniis } \\
\text { tuis }\end{array}$ & 5 & g00363 \\
\hline & & & & Intr-V & Beati immaculati in via* & 5 & g00363a \\
\hline & & & & Intr & $\begin{array}{c}\text { Me exspectaverunt } \\
\text { peccatores }\end{array}$ & 2 & g01373 \\
\hline \multirow[t]{5}{*}{ verso } & & Commune vv. (?) & & Intr & $\begin{array}{l}\text { Me exspectaverunt } \\
\text { peccatores* (cont.) }\end{array}$ & 2 & g01373 \\
\hline & & & & Intr-V & Beati immaculati in via* & 2 & g01373a \\
\hline & & & & Intr & $\begin{array}{l}\text { Vultum tuum depre- } \\
\text { cabuntur* }\end{array}$ & 2 & g01390 \\
\hline & & & & Intr-V & Eructavit cor meum* & 2 & g01390a \\
\hline & & & & Grad & $\begin{array}{l}\text { Dilexisti iustitiam et } \\
\text { odisti* }\end{array}$ & 8 & g01366 \\
\hline
\end{tabular}

Both the fragment from Budapest University Library, and the one from the Szombathely Diocesan Library would have been part of the commune sanctorum section of the gradual and adjacent in the original manuscript. ${ }^{28}$

\subsection{Fragments of the Sequentionale Waradiense}

One of the aims of fragmentology is to reconstruct hitherto unknown codices based on the study of the highest possible number of fragments. In specific cases, researchers can even piece together larger continuous sections of the same manuscript, or can complete sources that became fragmented through the

28 According to latest research by Gabriella Gilányi, there might be more fragmentary leaves from the same gradual preserved in various libraries and archives in Hungary. On the reconstruction of the manuscript, as well as to the unique type of musical notation see Gilanyi 2018. The description and analysis of the new discoveries made by Gilányi are available on the website Fragmenta Manuscriptorum Musicalium Hungariae Mediaevalis. 
centuries. The large-format, richly illuminated choirbooks of Várad Cathedral, written at the end of the fifteenth century, are some of the most fragmented liturgical music manuscripts in Hungary. ${ }^{29}$ The series presumably contained manuscripts for the Mass and the Office that included a two-volume antiphoner, a possible two-volume gradual, probably an independent kyriale, and a sequentiary. The large, display codices were used only for a short time in Varad; they were taken from the city in the first half of the sixteenth century, due to the advancing Turkish forces and protestant ideology gaining prominence. The fate of the manuscripts in the following centuries is still unknown. ${ }^{30}$ What remains of the two-volume antiphoner - about a third of the original manuscript - was found in the deposit of Györ Cathedral in Western Hungary in the 1860s. The damaged, truncated leaves were restored and rebound in 1872, ${ }^{31}$ and the manuscript is now hold in the Diocesan Library and Treasury of Györ. ${ }^{32}$ The other volumes of the hypothetical series - the gradual, kyriale and sequentiary - were lost, and information on their contents, structure, and musico-liturgical repertoire can only be inferred from a few surviving fragments. On the basis of comparative studies, the series of sequences originally contained about sixty chants, of which now only seven fragmentary sequences are known. ${ }^{33}$

Research conducted recently in the University Library of Budapest increased this number by another, new fragment (see Fig 4). This fragment is particularly important because it contains part of the sequence Plaudant chori monachorum for St Procopius, the Bohemian hermit and saint canonised in 1204. Procopius was not venerated in Medieval Hungary, and his sequence cannot be found in any other Hungarian source. ${ }^{34}$ How is it possible that the sequence appears in the gradual of Várad Cathedral? The answer may lie in the life of János Filipecz, bishop of Varad in the fifteenth century. ${ }^{35}$ Filipecz was of Moravian origin, and the administrator of the Olomouc bishopric see. It is possible that, when Filipecz became bishop of Várad, he commissioned the production of new chantbooks for

29 Várad/Nagyvárad, Waradinum (lat.), Grosswardein (ger.), Oradea in modern-day Romania. 30 See Körmendy 1988, 33-40; Czagány 2016a, 103-117.

31 The restoration in the 1860s was initiated by the Hungarian archeologist and art historian Flóris Rómer and promoted by János Zalka, bishop of Győr from 1867 until 1901.

32 Győr, Diocesan Library and Treasury, s. s. A facsimile edition of the antiphoner with critical apparatus and commentary was recently published by Czagány 2019.

33 See Czagány 2016b.

34 More on the Bohemian sources of the sequence Plaudant chori monachorum see the Index Sequentiarum Bohemiae Medii Aevi by Hana Vlhová-Wörner: <http://hymnologica.cz/sequences>. 35 János (Johannes) Filipecz, from 1469 was a diplomat, secretary and chancellor of King Matthias Corvinus, from 1477 until 1490 bishop of Nagyvárad. See Kalous 2001. 
the cathedral, probably compiled in one of the leading scriptoria of Bohemia or Moravia; the monumental rhombic notation and the rich decorative style of the manuscript are similar to that of many late fifteenth- and early sixteenth-century Bohemian codices. ${ }^{36}$
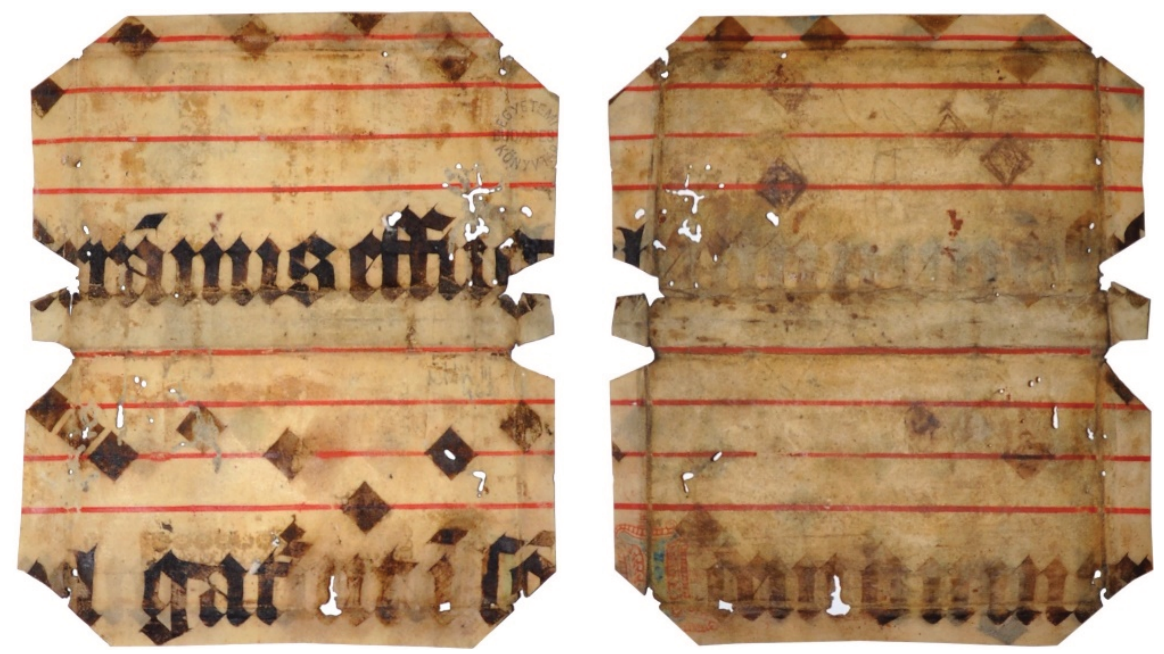

Fig. 4: Budapest, University Library, fragment removed from RMK III/463, recto (left) and verso (right); @ Budapest, University Library.

As can be deduced from the antiphoner, while the basic liturgical repertoire follows the medieval consuetudo of Varad ${ }^{37}$ at certain points, chants or chantcycles of the Bohemian Mass and Office tradition have been added, almost as an exotic touch. Such Bohemian elements are, for example, the historiae of St Martha ${ }^{38}$ and St Matthias ${ }^{39}$ in the antiphoner, or even the recently-discovered Procopius sequence, preserved as a fragment of a folio which once belonged to the lost Waradinum Sequentiary.

36 For example the gradual from Kuttenberg / Kutná Hora (Vienna, Österreichische Nationalbibliothek 15501), the Franus Cantionale (Hradec Králové, Muzeum Východních Čech II A 6), the gradual from Mladá Boleslav (Mladá Boleslav, Okresní muzeum inv. č. 21691). Cf. Czagány 2016a.

37 See Kovács 2010.

38 See Czagány 2004.

39 See Czagány 2009. 
These two case studies aimed at introducing the Fragmenta Manuscriptorum Musicalium Hungariae Mediaevalis database, as well as the prospects and goals of research on the material, which include linking the on-line database with other similar initiatives, in order to identify groups of fragments scattered throughout Europe, and reconstruct lost musical sources.

\section{References}

Czagány, Zsuzsa (ed.) (2004), Historia de sancta Martha hospita Christi, redactio Bohemica. Ein spätmittelalterliches Reimoffizium zu Ehren der heiligen Martha in seiner böhmischen Überlieferung (Musicological Studies series HISTORIAE 65/9), Ottawa: Institute of Mediaeval Music.

Czagány, Zsuzsa (2009), 'Historia sancti Mathiae apostoli - Wege eines spätmittelalterlichen Reihenoffiziums zwischen Prag und Trier', in Cantus Planus. Papers Read at the 13th Meeting, Niederaltaich, Germany, Aug. 29 - Sept. 4 2006, Budapest: Institute for Musicology of the Hungarian Academy of Sciences, 143-156.

Czagány, Zsuzsa (2016a), 'Das Itinerar einer spätmittelalterlichen Prunkhandschrift im 16-17. Jahrhundert. Fragmente des Antiphonale Waradiense in Levoča und Poprad', in Rastislav Adamko (ed.), Musica Mediaeva Liturgica, vol. II, Ružomberok: Katolícka univerzita v Ružomberku, Pedagogická fakulta, 103-129.

Czagány, Zsuzsa (2016b), 'Böhmische “Zutaten” im Waradiner Sequentiar', in Pawet Gancarczyk (ed.), Ars Musica and Its Contexts in Medieval and Early Modern Culture. Essays in honour of Elżbieta Witkowska-Zaremba, Warszawa: Liber Pro Arte, 237-245.

Czagány, Zsuzsa (2019), Antiphonale Varadinense s. XV, vol. I: Proprium de tempore; vol. II: Proprium de sanctis et commune sanctorum; vol. III: Essays (Musicalia Danubiana 26/13), Budapest: Research Centre for the Humanities, Institute for Musicology.

Deissmann, Adolf (1933), Forschungen und Funde im Serai. Mit einem Verzeichnis der nichtislamischen Handschriften im Topkapu Serai zu Istanbul, Berlin: De Gruyter.

Gilányi, Gabriella (2018), Használatitól a müremekig: a 15. századi hangjelzett esztergombudai kódexek [From Ordinary to Masterpiece: the Fifteenth-Century Notated 'EsztergomBuda' codices], in Gabriella Gilányi (ed.) Zenetudományi Dolgozatok 2015-2016. In memoriam Kiss Gábor, Budapest: Institute for Musicology of the Hungarian Academy of Sciences, 24-36.

Kalous, Antonín (2001), John Filipec: His Life and Personality, in Marcell Sebők and Katalin Szende (eds), Annual of Medieval Studies at CEU 7, Budapest: Department of Medieval Studies, CEU, 267-268.

Komáromy, András (1890), 'Báthory István országbíró végrendelete’ [The will of Stephen Báthory], in Századok, 24: 124-141.

Körmendy, Kinga (1988), Az ún. Zalka Antiphonale töredékei [The Fragments of the so-called Zalka Antiphonal], in Zenetudományi Dolgozatok [1988] (<http://real-j.mtak.hu/id/eprint/ 4694>): 33-40. 
Kovács, Andrea (2010), Corpus Antiphonalium Officii Ecclesiarum Centralis Europae, VII/A: Transylvania-Várad Temporale; VII/B: Transylvania-Várad Sanctorale, Budapest: Institute for Musicology of the Hungarian Academy of Sciences.

Madas, Edit, et al. (eds) (2006), Mittelalterliche lateinische Handschriftenfragmente in Sopron, Budapest: Akadémiai Kiadó.

Mezey, László (1973), 'A Fragmenta Codicum szabályzata’ [Statutes of the Fragmenta Codicum], in Magyar Könyvszemle, 89: 211-213.

Mezey, László (1978), ‘Fragmenta codicum. Egy új forrásterület feltárása’ [Fragmenta Codicum. Discovery of a New Source Field], in MTA Nyelv-és Irodalomtudományi Osztályának Közleményei, 30: 65-90.

Mezey, László, et al. (eds) (1983), Fragmenta Latina codicum in Bibliotheca Universitatis Budapestinensis [...], Budapest/Wiesbaden: Harrassowitz/Akadémiai Kiadó.

Mezey, László, et al. (eds) (1988) Fragmenta Latina codicum in Bibliotheca Seminarii cleri Hungariae centralis [...], Budapest/Wiesbaden: Harrassowitz/Akadémiai Kiadó.

Szendrei, Janka (1981), A magyar középkor hangjegyes forrásai [Notated Sources of the Hungarian Middle Ages] (Mühelytanulmányok a magyar zenetörténethez [Studies in Hungarian Music History] 1), Budapest: Institute for Musicology of the Hungarian Academy of Sciences.

Szendrei, Janka (1986), 'The Introduction of Staff Notation into Middle Europe', in Studia Musicologica Academiae Scientiarum Hungaricae, 28: 303-319.

Szendrei, Janka (1988a), 'Choralnotationen in Mitteleuropa', in Studia Musicologica Academiae Scientiarum Hungaricae, 30: 437-446.

Szendrei, Janka (1988b), ‘Geschichte der Graner Choralnotation', in Studia Musicologica Academiae Scientiarum Hungaricae, 30: 5-234.

Szendrei, Janka (ed.) (1993), Graduale Strigoniense (s. XV-XVI) (Musicalia Danubiana 12), Budapest: Institute for Musicology of the Hungarian Academy of Sciences.

Szendrei, Janka (1997), 'Choralnotationen in Polen', in Musica Antiqua Europae Orientalis, 10: 257-274.

Szendrei, Janka (1998), 'Perspektiven der musikalischen Paläographie in der Choralforschung', in Studia Musicologica Academiae Scientiarum Hungaricae, 39: 267-282.

Szendrei, Janka (2001), 'Mittelalterliche Choralhandschriften in Istanbul', in Cantus Planus. Papers Read at the 9th Meeting Esztergom \& Visegrád 1998, Budapest: Institute for Musicology of the Hungarian Academy of Sciences, 71-95.

Szendrei, Janka, et al. (eds) (1999), The Istanbul Antiphonal c.1360, Budapest: Akadémiai Kiadó.

Szigeti, Kilián (1962), ‘A magyar középkor zenei emlékei Szombathelyen’ [Musical Documents of the Hungarian Middle Ages in Szombathely], in Vasi Szemle, 16/2: 64-73.

Vadász, Veronika (2002), Ecsedi Báthory István végrendelete 1603 [The will of Stephen Báthory of Ecsed 1603] (Fiatal Filológusok Füzetei - Korai újkor 1), Szeged: SZTE.

Vízkelety, András (1989), 'Az Isztambuli Antifonále’ [The Istanbul Antiphoner], in Ars Hungarica, 17/1: 99-102.

Vizkelety, András (ed.) (2007), Mittelalterliche lateinische Handschriften der Széchényi Nationalbibliothek (Cod. Lat. 450-556), Budapest: Akadémiai Kiadó.

Vizkelety, András, et al. (eds) (1993), Mittelalterliche lateinische Handschriftenfragmente in Esztergom, Budapest/Wiesbaden: Akadémiai Kiadó/Harrassowitz.

Vizkelety, András, et al. (eds) (1998), Mittelalterliche lateinische Handschriftenfragmente in Györ, Budapest/Wiesbaden: Akadémiai Kiadó/Harrassowitz. 